\title{
Effectiveness of HOTS-Based Multiple Representation Learning Model in Circular Motion Material
}

\author{
Intan Kusumawati ${ }^{1}$, Sumarli ${ }^{2}$, Sutopo $^{3}$, Sentot Kusairi ${ }^{4}$ \\ STKIP Singkawang, Indonesia ${ }^{1,2}$, Universitas Negeri Malang, Indonesia ${ }^{3,4}$ \\ intank@stkipsingkawang.ac.id ${ }^{1}$, sumarliphysics@gmail.com ${ }^{2}$, sutopo.fisika@um.ac.id ${ }^{3}$, \\ sentot.kusairi.fmipa@um.ac.id ${ }^{4}$
}

Received: July $22^{\text {nd }}, 2019$. Revised: October $7^{\text {th }}, 2019$. Accepted: October $10^{\text {th }}, 2019$

\section{Keywords :}

Circular Motion; HOTS;

Multiple Representation;

Learning Model

\begin{abstract}
Students' Higher Order Thinking Skills (HOTS) can be honed by gradually developing new concepts from their multiple representation abilities through HOTS-based multiple representation learning models. This study aims to determine the effectiveness of the implementation of HOTS -based multiple representation learning models on circular motion material. The method used is in the form of quantitative research - the study design used preexperimental design. The sampling technique is purposive sampling of physics education students. It was found that HOTS-based multiple representation learning models on circular motion material effectiveness were achieved as expected in this study, the effectiveness of 1.06. The statistical hypothesis test used in the form of $U$ Mann Whitney with the results of Asymp. Sig. $0.04<0.05$, the hypothesis is accepted, meaning that there is the influence of the application of HOTS based multiple representation learning model on student learning outcomes in circular motion material. Improved learning outcomes were shown from the results of the average pretest score of 50.0 and the post-test of 85.9 with $N$-Gain of 0.7 in the high category. The positive response of students to the application of this learning model shows a percentage value of $96.7 \%$ with very strong.
\end{abstract}

\section{INTRODUCTION}

Multiple representations in several representations that were combined in imagining a thought of the problem at hand. Multiple representation can explore the reasoning that someone has in the form of descriptions of diagrams, graphs, and mathematics by the tendency of students to address problems. Multiple representations has an impact on understanding student concepts [1]. It was found that using multiple representations can improve physics learning outcomes [2]. It can be seen from their multiple representation abilities presented in various variations of representation [3]. Multiple representation constructing to learn in science [4] and it as alternative learning in physics [5], especially on changes in students' cognitive abilities [6]. This is because multiple representation is a way of explaining an 
object/process, idea, and reasoning for a problem [7]. Various problems caused by learning activities can trigger students to improve their representation ability [8]. Multiple representation ability can be used to sharpen HOTS students. Based on result of observation, implementation HOTS is not optimal. HOTS leads to the ability of students to be able to understand, analyze, categorize, manipulate, create, and apply new ways as a form of creative solutions [9]. In line with that, HOTS were oriented towards the ability to think critically, logically, reflective, meta cognitive, and creative thinking of students who are activated when students experience foreign problems, uncertainties, questions or dilemmas [10,11]. There are three types of HOTS in learning, namely HOTS as transfer, critical thinking, and problemsolving $[12,13]$. HOTS as a transfer leads to the delivery of information to students on specific concepts, HOTS as critical thinking is intended to be thinking that is critical of a problem at hand, while HOTS as a problem-solving means students were given various problems to solve. Assisting self-explanation can prompts in the learning [14]. HOTS was honed when learning improved the learning process. Multiple representation was a way to determine learning entities that could help students in each element of learning [15]. Thus, multiple representations that can have an effect on HOTS students, so HOTS in this study was presented in multiple representation learning models.

This HOTS-based multiple representation learning model is designed explicitly as learning that can be carried out continuously. Students find new concepts based on concepts that are built-in stages through various forms of representation step by step [16,17], namely Diagram (D), Graph (G), Mathematical $(\mathrm{M})$, and Verbal (V). This is because the DGMV is considered appropriate in the study of circular motion material. Students are directed to elicit an understanding of concepts in the form of diagrams (drawings) first, then followed in the way of graphical and mathematical representations, which are ended verbally by following the syntax of HOTS-based multiple representation learning models.

HOTS-based multiple representation learning models were designed with the syntax pattern detailed as follows [18]: 1) Orientation. Submission of learning/lecture objectives, learning procedures, and apperception takes the form of demonstrations that produce stimulus in building concepts with certain representations; 2) Challenges and Discussion. Problems are presented with electronic learning media to create specific images. Discussion and question and answer takes place at this stage. This stage is carried out continuously at each different representation; 3) Analysis. Together analyze the findings of the concepts that are built by each group according to the predetermined sequence of descriptions, and compare them with the scientific concepts; 4) Reflection. Feedback is given in the form of student responses to understanding the material to the provision of enrichment problems in the form of representation.

The implementation of this HOTS-based learning model is part of the problem examined in this study, which is related to the effectiveness of the HOTS-based learning model. This learning model is designed with four learning steps and is designed in such a way as to be easily applied in determining without reducing its essence, which includes HOTS. HOTS, in the syntax of this learning model, is at the stage of challenge and discussion, analysis, and reflection. Problems are given to students to be solved through a form of representation carried out with group discussions of reasoning and basic knowledge they have based on the stimulus given at the orientation stage.

The stimulus from this orientation stage is a demonstration of creating an object in a flat plane and an inclined plane (which is made using wood and glass/mirror material) to be explored more deeply by the students from the stages of the challenge and discussion. Furthermore, an analysis was carried out with the group to analyze the concepts that had been built by each group and were analyzed based on the scientific idea so that students realized the side directly that they still did not understand or understood. Reflection is carried out in the form of giving questions in the form of enrichment so that knowing the understanding of students' concepts on the concepts that are completed uses various types of representation independently. The goal of implementing HOTS-based multiple representation learning models is ultimately to be able to improve students' critical and creative thinking skills by HOTS coverage through the ability of students to understand and construct the concept of circular motion through various forms of representation. This study aims to test the effectiveness of the implementation 
of HOTS student-based multiple representation learning models on circular motion material. This study is expected to show that HOTS student-based multiple representation learning models influence student learning outcomes and can improve student learning outcomes in circular motion material.

Based on this description, there are various techniques (verbal, diagram, graph, and mathematical) in representing objects, processes, events, and problem-solving in a concept, each student has multiple representation abilities that need to be explored in understanding concepts, each variation of representation can work together strengthen in bringing up/instilling new ideas of understanding for students, there have never been a multiple representation learning models with learning patterns that synergize various forms of representation in stages to bring new concepts to students by honing their HOTS.

This research is expected to be an innovation that inspires the learning pattern of Physics, can be implemented in learning continuously both in circular motion material and other material and can be used as a pillar for further research.

\section{METHOD}

\section{Research Type and Design}

Quantitative descriptive method was used in this study with the research design in the form of preexperimental design in the way of one group pretest post test design. The sampling technique is purposive sampling with six participant. Pretest, post test, and student response sheets are used instrument in this study. The data collection instruments of this study were in the form of three essay test sheet that consist of analysis (C4), evaluation (C5), and create (C6); student response sheets with nominal scale for HOTS-based multiple representation learning models on circular motion material as many as 10 positive statements.

\section{Data Analysis Technique}

The implementation of this learning model is in the form of treatment given after the pretest, and before being given the post-test along with the student response questionnaire on the learning model. The validity and reliability of the data were processed using the help of Statistical Package for Social Science (SPSS) software version 17.0, with the results found indicating that the circular motion test instrument for each item was declared valid with a total score of $r_{\text {obtained }}>r_{\text {critical }}$ or $1>0.707$ with sig. $5 \% ; 0.834$ with sig. $1 \%$. The reliability results of circular motion test instruments were declared reliable with score 0.851 .

To test the effectiveness of the implementation of HOTS-based multiple representation learning models in this study following the steps:

1. Determine the level of achievement of efficiency.

The level of effectiveness of HOTS-based multiple representation learning models on circular motion material according to the definition of effectiveness stated by J. R. Jr. Schemerhon in 1986, that is calculated [19] through the following equation.

$$
\text { Effectiven ess }=\frac{\text { obtained score }}{\text { expected score }} \geq 1
$$

Adopted with slight changes, based on these equations, it can be concluded that :

a. If the results of the comparison of scores obtained with the expected score $<1$, then the effectiveness is not achieved,

b. If the effects of the similarity of scores obtained with the expected score $\geq 1$, subsequently efficiency is achieved. 
2. Assess the effect of learning models on learning outcomes through statistical hypothesis testing. Processing and analysis of statistical data in this study are assisted by SPSS version 17.0. To determine the statistical hypothesis test that is appropriate in processing data, it begins with the data Normality test using Kolmogorov Smirnov. After that, the data homogeneity test was carried out using One Way ANOVA. If the data is typically distributed and homogeneous, the parametric statistical analysis is in the form of a t-test, but if the data found is not similar, non-parametric statistical tests are carried out in the way of U Mann Whitney so that the hypothesis can be accepted or rejected. Hypothesis accepted if the results of Asymp.Sig < 0.05, but if the results of Asymp.Sig > 0.05, so hypothesis rejected [20]. The assumption in this study is that there is a difference between learning outcomes before and after HOTSbased multiple representation learning models are applied to circular motion material. If there is a significant difference, then there is the effect of using HOTS-based multiple representation learning models on student learning outcomes in circular motion material.

3. Determine the magnitude of improvement in learning outcomes through the $\mathrm{N}$-Gain equation.

Furthermore, it was sought to increase student learning outcomes before and after the treatment was given in the form of implementation of HOTS-based multiple representation learning models on circular motion material. The magnitude of the increase in learning outcomes can be determined using the NGain equation stated by Hake in 1998 [21] as follows.

$$
N-\text { Gain } \quad(g)=\frac{s_{\text {posttest }-s \text { pretest }}}{s_{\max \text { imum }}-s \text { pretest }}
$$

4. Determine the percentage of positive responses of students to HOTS-based multiple representation learning models on circular motion material

The results found are reinforced by the rate of positive reactions of students to HOTS-based multiple representation learning models on circular motion material can be determined using percentage responses equation. The results obtained from these equations can be compared with the interpretation of the percentage of student response scores, which are shown in table 1 [22] as follows.

Table 1. Interpretation of Percentage of Student Response Scores

\begin{tabular}{cc}
\hline Percentage $(\%)$ & Criteria \\
\hline $0 \leq \mathrm{NRS}<20$ & Very weak \\
$20 \leq \mathrm{NRS}<40$ & Weak \\
$40 \leq \mathrm{NRS}<60$ & Enough \\
$60 \leq \mathrm{NRS}<80$ & Strong \\
$80 \leq \mathrm{NRS} \leq 100$ & Very strong \\
\hline
\end{tabular}

\section{RESULTS AND DISCUSSIONS}

It was found that the scores obtained in this study were taken from the total post-test score from student answers, which was equal to 515.4. The expected rating is obtained from a minimum score multiplied by the number of participants. The minimum score in this study is 81 , which is a minimum value to get an $A$ at the college where the sample is taken, so the expected count in this study is 486 . The effectiveness of this study was found to be $1.06>1$, then the learning model HOTS-based multiple representations on circular motion material has reached the expected efficiency in this study. The effectiveness in this study was achieved and is in the high category through the N-Gain equation. These results were obtained from the pretest and post test results of students which showed that the average score of the higher post test of pretest in the sense that there was an increase in learning outcomes after applying the hots-based multiple representation learning model. This learning model has an influence on learning outcomes and can improve student learning outcomes in circular motion material. 
The results of the Normality test using the Kolmogorov Smirnov equation show a significance value of $0.992>0.05$; it can be concluded that the data are normally distributed, as presented in table 2 below.

Table 2. Test the normality of test results data

\begin{tabular}{cc}
\hline & Unstandardized Residual \\
\hline $\mathrm{N}$ & 6 \\
Asymp Sig. (2-tailed) & .992 \\
\hline
\end{tabular}

Then the data homogeneity test using One Way ANOVA, found a significance value of $0.02<0.05$, which indicates that the data is not homogeneous, as shown in table 3 as follows.

Table 3. Test the homogeneity of test results data

\begin{tabular}{cc}
\hline & Results Data \\
\hline N (df) & 10 \\
Sig. & .020 \\
\hline
\end{tabular}

The data found were normally distributed, but not homogeneous, so non-parametric statistical tests were used in the form of U Mann Whitney in the statistical hypothesis test.

Table 4. Non-parametric statistical test of U-Mann Whitney test results data

\begin{tabular}{cc}
\hline & Results Data \\
\hline $\mathrm{N}$ & 6 \\
Asymp Sig. (2-tailed) & .004 \\
\hline
\end{tabular}

Based on the results of data processing, according to table 4, the results of Asymp.Sig $(0.04)<0.05$. This shows that the hypothesis is accepted [20] with meaningfull median distribution Meaning that there is a difference between learning outcomes before and after the HOTS-based multiple representation learning models is applied to circular motion material because there are significant differences. It can be said that "there is" the influence of the use of HOTS-based multiple representation learning models on student learning outcomes in circular motion material. This result show that multiple representation learning model based on HOTS has an impact on student learning outcomes.

Improved learning outcomes are shown from the results of the average pretest score of 50.0 and the post-test at 85.9 , and the maximum score of 100 , then using equation 1 ) obtained N-Gain of 0.7 in the high category. The average pretest and post-test values in circular motion material are shown in Fig 1 as follows.

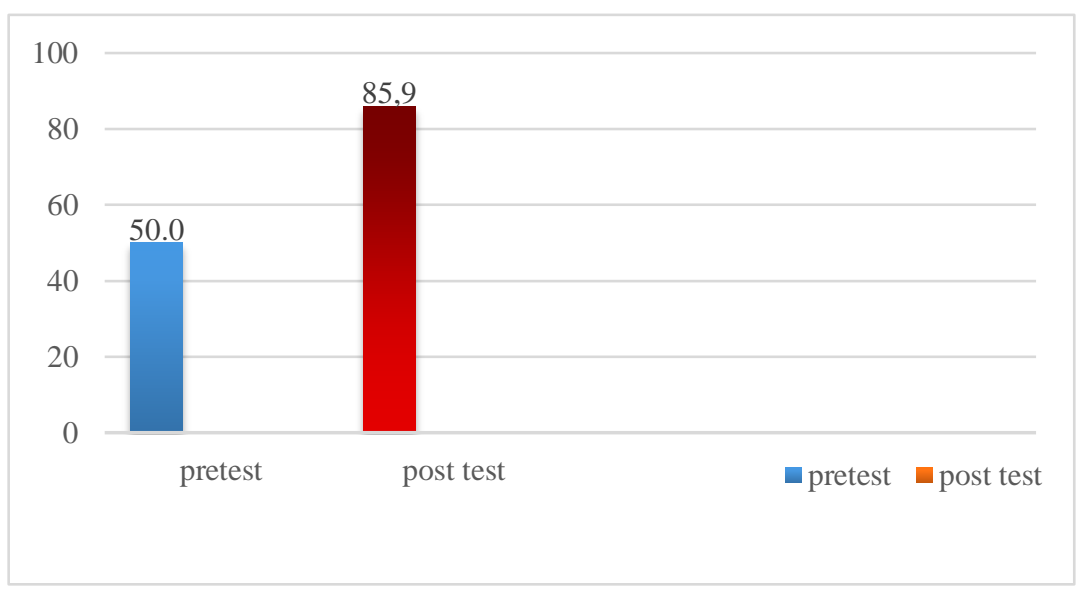

Fig 1. Comparison of The Average Score Pretest and Post-test 
Figure 1 shows that there was an increase before and after the treatment was given in the form of the implementation of HOTS-based multiple representation learning models on circular motion material. The post-test results showed a higher score than the pretest because before the post-test students were given treatment in the form of HOTS-based multiple representation learning models. This change shows that the learning model is effective in improving student learning outcomes. This is reinforced by previous research $[23,24]$ found that multiple representations can measure students' understanding of concepts through the given tests, while other studies [25, 26,27] find that multiple representation learning models can improve learning outcomes and or understanding student concepts. This is because of multiple representations of learning outcomes and knowledge of student concepts by utilizing HOTSbased representations, students can build the idea of circular motion by using the HOTS they have in physics, HOTS of students and the ability of students to describe the results of understanding their concepts in the form of multiple representation are sufficiently honed through the application of this learning model.

Calculation of the results of student response data is known that the score obtained is 58, and a maximum score of 60 , so the percentage value of positive student responses to HOTS-based multiple representation learning models in circular motion material is $96.7 \%$ with very strong. Aspects of the learning process so that students respond well including: reliefs, interests, and change. Based on the data found that effectiveness is achieved as expected, there are a significant influence and increase in student learning outcomes, as well as positive responses of students to the application of HOTS-based multiple representation learning models to circular motion material. The advantages of the learning model used to improve learning outcomes, which can hone the HOTS of students through their multiple representation capabilities, the learning model is easy to apply in learning, the stages in the syntax of the learning model lead to success in learning. Thus, the HOTS student-based multiple representation learning models is feasible to be applied in physics learning, especially in circular motion material.

HOTS sharpening through multiple representation learning models can provide a new picture for students as a way to solve problems that can be described through various forms of representation. In this study students who in their learning activities are required to be able to develop their own concepts in a variety of forms of representation cause optimal HOTS skills honed. This is shown from the learning outcomes that differ significantly, before and after learning activities with this multiple representation learning model. It was found that students were able to answer HOTS questions that were given well after learning with a multiple representation learning model. Structured and systematic learning in developing student concepts to hone HOTS from existing representations is an advantage in this study because there has never been learning with learning patterns like this and this learning model is proven to be able to improve student learning outcomes by honing HOTS students on circular motion material.

\section{CONCLUSION AND SUGGESTION}

HOTS-based multiple representation learning models are useful for improving student understanding of concepts. The effectiveness test shows that the HOTS student-based multiple representation learning models on circular motion material is achieved in accordance with the expected results in this study; there is the influence of HOTS-based multiple representation learning models on student learning outcomes; there is an increase in student learning outcomes in circular motion material after HOTSbased multiple representation learning models is applied at 0.72 with a high category; and a positive response of $96.7 \%$ with very strong criteria given by students to HOTS-based multiple representation implementation on circular motion material. Implication in research is HOTS students can honed through application multiple representation learning model, and students' multiple representation abilities vary so that the results of the effectiveness of this learning model can also vary. The limitation of this research is that the learning model applied is tested for effectiveness on just one material, involving only one sample class, and the results only apply to the class where the research sample was taken. Learning model in this research is expected to apply and determine to material physics other. 


\section{ACKNOWLEDGMENTS}

Thank you to the Directorate of Research and Community Service; Directorate General of Research and Development Strengthening; The Ministry of Research, Technology and Higher Education for the assistance of Grant for Beginner Lecturer Research Funds (PDP) given in the fiscal year 2019, so that the research activities can run smoothly. Thank you also addressed to STKIP Singkawang for the permission granted in conducting this research.

\section{REFERENCES}

[1] Suhandi, A., \& Wibowo, F. C. (2012). A Multi Representation Approach in Work-Energy Learning and Impact on Students' Understanding of Concepts. Jurnal Pendidikan Fisika Indonesia, 8(1).

[2] Kusumawati, I., Kahar, M. S., Khoiri, A., \& Mursidi, A. (2019, February). Differences analysis understanding the concept of students between the three islands (Java, Kalimantan, Papua) through multiple representations approaches to the material of Time Dilation. In Journal of Physics: Conference Series (Vol. 1153, No. 1, p. 012145). IOP Publishing.

[3] Prain, V., \& Tytler, R. (2013). Representing and learning in science. In Constructing representations to learn in science (pp. 1-14). Brill Sense.

[4] Irwandani. (2014). Multirepresentations as Alternative Learning in Physics. Jurnal Ilmiah Pendidikan Fisika Al-Biruni, 3(1): 39-48.

[5] Widianingtiyas, L., Siswoyo, \& Bakri, F. (2015). Effect of Multi Representation Approaches in Physics Learning Against Cognitive Abilities of High School Students. Jurnal Penelitian dan Pengembangan Pendidikan Fisika, 1(1): 31-37.

[6] Yusuf, M., \& Setiawan, W. (2009). Student Multirepresentation Competency Study on Electrostatic Topics. Jurnal Pendidikan Teknologi Informasi dan Komunikasi, 2(1): 1-10.

[7] Rosyid. (2013). Improving Physics Learning Outcomes using the Science Orientation Model (PBL and Multi Representation) on the Concept of Mechanics in High School. Jurnal Pancaran, 2(3): 112.

[8] Artha, Bharata, H., \& Caswita. (2014). Application of Problem Based Learning Model to Improve Students' Mathematical Representation Ability. Jurnal Pendidikan Matematika, 2(4): 1-10.

[9] Thomas, A., \& Thorne, G. (2009). Higher Level Thinking-It's HOT! The Center for Development and Learning. http://www.cdl.org/articles/higherorder-thinking-its-hot/.

[10] King, F. J., Goodson, L., \& Rohani, F. (2010). Assessment \& evaluation educational services program: Higher-order thinking skills. Washington, DC: A publication of the Educational Services Program.

[11] Riyadi, A. (2016). Problem Based Learning Increases Higher Order Thinking Skills of Class VIII Students at SMP 1 Daha Utara. Jurnal Pendidikan Matematika, 2(3).

[12] Brookhart, S. M. (2010). How to assess higher-order thinking skills in your classroom. ASCD.

[13] Abdullah, A. H., Abidin, N. L. Z., \& Ali, M. (2015). Analysis of students' errors in solving Higher Order Thinking Skills (HOTS) problems for the topic of fraction. Asian Social Science, 11(21): 133.

[14] Berthold, K., Eysink, T. H., \& Renkl, A. (2009). Assisting self-explanation prompts are more effective than open prompts when learning with multiple representations. Instructional Science, 37(4): 345-363.

[15] Astuti, Y. W. (2013). High School Physics Teaching Materials with Multi Representation Approach. Jurnal Pendidikan Sains, 1(4): 382-389.

[16] Abdurrahman, A., Liliasari, L., Rusli, A., \& Waldrip, B. (2011). Implementasi pembelajaran berbasis multi representasi untuk peningkatan penguasaan konsep fisika kuantum. Cakrawala Pendidikan, (1).

[17] Setyandaru, T. A., Wahyuni, S., \& aristya Putra, P. D. (2017). Pengembangan Modul Pembelajaran Berbasis Multirepresentasi pada Pembelajaran Fisika di SMA/MA. Jurnal Pembelajaran Fisika, 6(3): 223-230. 
[18] Kusumawati, I., Sumarli, Sutopo, \& Kusairi, S. (2019, December). Development of multiple representation learning model based on HOTS students in straight motion material. In AIP Conference Proceedings (Vol. 2194, No. 1, p. 020052). AIP Publishing LLC.

[19] Karambut, C. A. (2017). Pengaruh Keselamatan dan Kesehatan Kerja Terhadap Efektivitas Kerja Pada PT. Asri Griya Utama, Project Holland Village Manado. Manajemen dan Bisnis, 1(2).

[20] Sugiyono. (2014). Statistika untuk Penelitian. CV Alfabeta: Bandung.

[21] Handayani, R. A., Sukarmin, \& Sarwanto. (2018). Development of Multirepresentation Physics Module Based on Problem Based Learning on the Material of Rotational Dynamics and Firm Object Equilibrium to Improve Critical Thinking Skills of Class XI High School Students. INKUIRI: Jurnal Pendidikan IPA, 7(3): 352-364.

[22] Alatas, F. (2019). Developing Simple Teaching Aids On Static Fluid Material As A Learning Media For Physics. Jurnal Pendidikan Fisika-Journal of Physics Education, 7(2): 197-211.

[23] Ertikanto, C., Rosidin, U., Distrik, I. W., Yuberti, Y., \& Rahayu, T. (2018). Comparison of Mathematical Representation Skill and Science Learning Result in Classes with Problem-Based and Discovery Learning Model. Jurnal Pendidikan IPA Indonesia, 7(1): 106-113.

[24] Yusup, M. (2009). Multirepresentasi dalam Pembelajaran Fisika. Jurnal Pendidikan Teknologi Informasi dan Komunikasi, 2(1): 1-7.

[25] Uslima, U., Ertikanto, C., \& Rosidin, U. (2018). Contextual Learning Module Based on Multiple Representations: The Influence on Students' Concept Understanding. Tadris: Jurnal Keguruan Dan Ilmu Tarbiyah, 3(1): 11-20.

[26] Finnajah, M., Kurniawan, E. S., \& Fatmaryanti, S. D. (2016). Development of Multi Representation Based High School Physics Modules to Improve Understanding of Concepts and Learning Outcomes. Jurnal Radiasi, 8(3): 22-27.

[27] Mahardika, I. K. (2018). Application of Concept Based Interactive Learning Model to Improve Verbal, Mathematical, and Physics Representation Ability of Class VIII-A Students MTs N 1 Jember 2012/2013 Academic Year. Jurnal Pendidikan Fisika, 2(3): 272-277. 